\title{
Anti-corporate activism and market change: The role of contentious valuations
}

Sophie Dubuisson-Quellier (Centre de sociologie des organisations, CNRSSciences Po)

\begin{abstract}
The contentiousness of markets has recently been assessed by the social movements literature. Activists can use a broad range of tactics to compel corporations to change their practices. This paper examines the outcomes of this contentiousness. It draws on an empirical study of a disruptive tactic used by anti-corporate activists: the shame-on-you prize. I propose to adopt an economic sociological perspective to understand the mechanisms by which social movement organizations seek to undermine the values that underpin the economic order. Activists provide new categories for valuating economic activities that challenge the existing ones. Social movement organizations legitimate these valuations as coming from civil society and reflecting public expectations about what should count in valuations of economic activities. As such, they may encourage public decision-makers to undertake regulatory action.
\end{abstract}

Keywords: anti-corporate activism, markets, social change, valuation, companies.

\section{Correspondence Address:}

Centre de sociologie des organisations (Sciences Po/CNRS)

27 rue Saint Guillaume 75337 Paris cedex 07 France

Sophie.dubuissonquellier@sciencespo.fr

\section{Notes on Contributors}

Sophie Dubuisson-Quellier is research professor and deputy director of the Center for the Sociology of Organizations in Paris (Sciences Po/CNRS). Her research, in the field of economic sociology, aims at understanding how consumers' economic behaviour is shaped by corporations, public policies, and social movements. She has published Ethical Consumption (2013) and Gouverner les Conduites (2016). Her work has appeared in several academic journals such as Organization Studies, Journal of Consumer Culture, Sociologia Ruralis, and International Journal of Consumer Studies. 


\section{Author Links}

Sophie Dubuisson-Quellier ORCiD ID: 0000-0001-5341-0431

Sophie Dubuisson-Quellier Social Media Profiles: @SDubuissonquell

Acknowledgements: [if relevant]

Funder details: This work is supported by a public grant overseen by the French National

Research Agency (ANR) as part of the "Investissements d'Avenir" programme LIEPP (reference: ANR-11-LABX0091, ANR-11-IDEX-0005-02). 


\title{
Anti-corporate activism and market change: The role of contentious valuations
}

\begin{abstract}
The contentiousness of markets has recently been assessed by the social movements literature. Activists can use a broad range of tactics to compel corporations to change their practices. This paper examines the outcomes of this contentiousness. It draws on an empirical study of a disruptive tactic used by anti-corporate activists: the shameon-you prize. I propose to adopt an economic sociological perspective to understand the mechanisms by which social movement organizations seek to undermine the values that underpin the economic order. Activists provide new criteria for valuating economic activities that challenge the existing ones. Social movement organizations legitimize these valuations as coming from civil society and reflecting public expectations about what should count in valuations of economic activities. As such, they may encourage public decision-makers to undertake regulatory action.
\end{abstract}

Keywords: anti-corporate activism, markets, social change, valuation, companies.

\section{Introduction}

In 2015, at the 21st Conference of the Parties (COP21) in Paris, many large French companies were offered great opportunities to develop their institutional communication. As sponsors, they could set up a stand in the exhibition part of the conference to demonstrate their commitment to sustainability or to obtain access to leading figures from around the world and exert their lobbying power. Another exhibition, called Solutions COP21, dedicated to a larger audience, was held at the Grand Palais, where various large corporations proposed to offer participants a full 'climate experience'. According to the French Minister of Foreign Affairs, corporations have never been so active on environmental issues. He called them 'friends of climate', a phrase that contrasts with activist Naomi Klein's denunciation of large corporations as 'climate criminals' during the same conference. These observations demonstrate the power of economic interests in international climate negotiations, but they also suggest that corporations make extensive use of symbolic resources on environmental issues to communicate with a wide audience, an area on which environmental activists previously held a monopoly. As a result, while environmental non-government organizations (NGOs) denounce the environmental damage caused by the economic activities of irresponsible globalized 
corporations and pursue social justice to rehabilitate the environment, corporations engage in significant institutional communications to promote their climate actions. In the middle of this struggle, governments seem to oscillate between defending economic interests and regulating them in response to public scandals and under pressure from civil society.

Activists and corporations fight one another publicly; this contentiousness in markets has recently been assessed in the social movement literature (Soule 2009; King and Pearce 2010). Activists use a broad range of tactics, from insider activism (Raeburn 2004) to disruptive strategies, such as naming-and-shaming campaigns or calls for boycotts, to attempt to force corporations to change their practices (Bartley and Child 2014). This raises questions about the outcomes of this contentiousness. Could it have an effect on companies' practices, on the way they pursue their activities? The literature has emphasized the continuous influence that NGOs may have on business behaviour (den Hond and de Bakker 2007), while acknowledging that companies respond to social movements' disruptive actions strategically rather than acceding to their demands (Locke 2013). In return, social movement organizations (SMOs) may adapt their tactics to increase their pressure on companies. The literature has described a back-andforth between activists and their targets (Balsiger 2016; 2018). How can we account for the effects of these contentious interactions in terms of market change?

To answer this question, I draw from two sets of literature. The first comes from social movement studies and considers the mediated effects of anti-corporate activism (King 2008; 2011). These mediation models emphasize the role of media coverage, economic and market structures, and the threat of state regulation in assessing the influence of activism on business behaviour. The second comes from the field of economic sociology and relies more directly on the burgeoning literature on valuation. This literature has demonstrated that the economic world is full of debates about how actors and activities are valuated, based on the criteria and on who have the legitimacy to define what is valuable (Beckert and Aspers 2010; Fourcade 2011). I state that one of the mediated effects of anti-corporate activism comes from its capacity to undermine valuations that circulate in the business world and to spread alternative valuations based on criteria that include the externalized costs of economic activities (such as environmental damage or human rights violations). Activists may then achieve some kind of effectiveness when these alternative valuation criteria become legitimate as the expression of the common good and succeed in convincing some companies to adopt them and public decision-makers to undertake regulation. To support this argument, I draw on a specific case study: the use of a shame-on-you prize tactic by a large environmentalist organization, which 
was designed to push for the regulation of globalized companies in order to make them accountable for the unethical practices of their suppliers and subcontractors.

In the first part of the paper, which draws from the literature on the contentiousness of markets, I recall that this literature has mostly emphasized the way in which anti-corporate actions undertaken by activists in the 1990s challenged firms' reputations. I then suggest that the theoretical framework of valuation studies can question the broader process of valuation that is engaged when reputations are challenged. SMOs may participate in valuating economic activities by claiming themselves to be legitimate to express public expectations about what companies should be accountable for. The second part of the paper outlines the specific disruptive tactic that I take as an empirical case: a shame-on-you prize tactic developed by a French environmentalist SMO. Finally, in the last part, I demonstrate that this naming-andshaming tactic intended to produce alternative categories of valuation to challenge existing valuations in the business world. It was claimed that this alternative valuation expressed public expectations of what companies should be accountable for. It provided the possibility for SMOs to engage in discussions with targeted companies about appropriate, valuable, and ethical business practices and also to gain allies in parliament in order to push forward a regulation to enforce companies to monitor their suppliers' activities. In the conclusion, I outline the paper's contributions to both the literature on social movement outcomes and that on market change.

\section{From reputation to valuation: Towards an economic sociological perspective on the disruptive tactics used by SMOs}

Having previously focused primarily on how activists target governments, scholars have only recently considered the ways in which social movements put pressure on companies and market actors, despite the phenomenon not being new and having been extensively documented by historians (see, for example, Trentmann 2001 or Glickman 2009). In the context of the antiglobalization protests of the 1990s, NGOs threatened globalized corporations by asserting claims for social justice, workers' rights, and the environment. The anti-sweatshop movement's campaign against Nike or the Rainforest Action Network's campaign against Home Depot became iconic of this anti-corporate activism. Facing this contentiousness, companies have engaged in significant communication activities to promote what they claim to be best practices and to defend their reputations (Baron 2016), leading scholars to study this form of activism through its reputational stakes. 


\subsection{Reputation as a central mechanism in studying the effects of anti-corporate activism}

Indeed, the literature has demonstrated how reputation mechanisms play a key role in anticorporate activism (King 2014). Contentious interactions between SMOs and companies have indeed been reinterpreted as engaging symbolic dimensions rather than economic ones. Furthermore, such a perspective is reinforced by the fact that the literature has acknowledged companies' reluctance to commit to major changes. Corporations have developed a wide repertoire of tactics to respond to and to adapt to the disruptive interventions of activists. Some corporations have developed public relations skills and campaigns either to enhance their reputations, to discredit activists' claims and accusations, or to avoid compliance with the standards promoted by social movement organizations (Locke 2013). McDonnell and King (2013) state that when companies are threatened and publicly challenged, they may use impression management tools in an attempt to control and influence their public perception. For example, corporations often engage in claims of pro-social behaviour when they do not want to concede to the demands of social movements (McDonnell and King 2013). This strategy has two advantages: the company avoids responding directly to the activists' accusations; and it builds its reputation without recognizing any legitimacy in the activists' claims. Moreover, some studies tend to acknowledge the limitations of disruptive activism due to the non-linear relationship between corporate behaviour and reputation. Contrary to what common sense would suggest, irresponsible behaviour by companies does not always lead to reputational sanctions. For example, Jackson and Brammer (2014) provide evidence that firms associated with irresponsibility may have better reputation scores than those not associated with such behaviour. These findings confirm companies' ability either to escape the vigilance of civil society by moving their activities away, making them less visible to a large audience, or to represent their image in such a way as to challenge accusations of irresponsibility or misbehaviour by social movement organizations.

As a result, the literature ambiguously focuses on reputation to assess anti-corporate activism, while at the same time recognizing the strong ability of companies to control their reputations. Because reputation is a notion specific to the business world rather than an analytical concept, its use as a proxy for the effects of activism remains problematic. I suggest using instead the concept of valuation to question anti-corporate outcomes. 


\subsection{Introducing a valuation perspective to assess how SMOs seek to achieve market change}

By focusing excessively on reputational aspects, the literature has certainly provided a better understanding of the symbolic struggle between companies and SMOs, but it leaves many questions open. If corporate reputations are the target of SMOs' disruptive actions, but companies have many resources to defend their reputations, what kind of change can activists expect from their actions? McDonnell and King suggest that scholars pay more attention to the symbolic outcomes of movements' activities. They consider that movements' influence over markets is 'inherently grounded in symbolic understandings about what is valuable and appropriate' (McDonnell and King 2013, 410). Valuation is a central mechanism at work in markets, and economic sociologists have become significantly more active in researching this issue.

The notion of valuation has been developed to shed light on the way in which market entities are attributed value in market structures (Beckert and Aspers 2010). Valuation is a broad social process involving cultural, cognitive, and political resources (Karpik 2010; Fourcade 2011), but it is not necessarily convergent. Indeed, there are multiple valuation processes at work in markets, many orders of worth, and several valuations of the same entities may co-exist and conflict with one another. These conflicting situations have been more specifically assessed for contested commodities (Radin 1996), when market and civil society actors debate the legitimacy of the commoditization of certain products or activities. These conflicting valuations may result from the competition process or the co-ordination of market activities (DubuissonQuellier 2013a), but they most certainly emerge because of civil society organizations. Social movement organizations may negotiate the boundaries of market activities (Zelizer 1979) and they may also provide the market with new values (Dubuisson-Quellier 2013b). These conflicting valuation processes produce disruption in the economy because of the dissonance they create for market operators (Stark 2009). Stark and colleagues have studied these moments of valuation broadly within organizations, in which dissonance may lead to change and innovation (Berthoin Antal et al. 2015).

I suggest that contentious interactions between social movement organizations and companies reveal conflicting criteria for the valuation of economic activities: notions such as efficiency, profitability, eco-friendliness, or ethics can be subject to huge variations in interpretation by these actors. Values are not given but are socially constructed, strongly connected to social 
expectations, and derived from the social processes of valuation and attribution. They are relative, time-contingent, and highly subjective (Jackson and Brammer 2014). In this paper, I highlight how categories of valuation, such as being ethical or green, are fiercely debated by companies and activists, in terms of the criteria that should be used to assess ethics or ecofriendliness. This contentiousness produces conflicting valuations of economic activities.

The conditions in which alternative valuations of economic activities compete are precisely what is at stake in this contentiousness of markets. Activists intend to participate in the definition of ethical business practices and to not let them be defined by companies. Both compete to set the relevant criteria and to convince the wider public of their validity. Indeed, drawing from the pragmatist framework (Dewey 1939; Kjellberg and Mallard 2013), valuation is defined as a specific process that intends to gather publics and produce collective norms: it is about convincing audiences of values, of modes of valuating, and of what is valuable. Activists try to convince large audiences about the relevance of their valuation of suitable, acceptable, and ethical business activities. I make the assumption that the circulation of activists' valuations can have some effect on markets.

\section{Presentation of the case study: Data and methods}

To answer the question of what may produce contentious interactions between SMOs and companies, I draw on a specific case study: a shame-on-you prize tactic developed by Friends of the Earth France.

Friends of the Earth France (Les Amis de la Terre France; AT) was created in 1970. It is a network of about thirty local groups fighting for social and environmental justice ${ }^{1}$. The organization develops three lines of action: information and representation to promote alternative solutions; awareness campaigns targeted at large audiences; and citizen mobilization in non-violent collective action. From 2008 to 2015, AT organized shame-on-you prizes events, called the Prix Pinocchio (Pinocchio Awards), to shed light on what it considered to be the worst cases of human and workers' rights violations or environmental damage committed by corporations. Three awards were created: the human rights award (the 'One for all, all for me!'

\footnotetext{
${ }^{1}$ In 1971, Friends of the Earth France, along with three of its counterparts from Sweden, the United Kingdom, and the United States, founded Friends of the Earth International. Today, it is one of the world's largest and most legitimate grassroots environmental networks. It is present in seventy-five countries with more than two hundred local groups and over two million members. The organization is well known for challenging the current model of economic and corporate globalization.
} 
award), the environment award (the 'Dirty hands, full pockets' award), and the greenwashing award (the 'Greener than green' award). The approach worked as follows: after local investigations of company misbehaviour in France or abroad, the organization nominated three corporations for each of the three awards. The list of nominated corporations was published on the organization's website, on partner NGOs' websites, and in the press, to encourage citizens to vote for a company. At the end of the voting process, the prizes were awarded to three companies during a parodic public ceremony, filmed and posted on the internet and reported by the media. A press release presented the details of the companies' actions that had been condemned and given an award by the organization.

The shame-on-you prize tactic is a naming-and-shaming action that is used by several NGOs targeting corporations. For example, from 2005 to 2015, the Déclaration de Berne, in partnership with Greenpeace Switzerland, held the Public Eye Awards to punish companies for unethical behaviour, such as violations of human rights, poor working conditions, environmental damage, lack of transparency, and corruption. Several other shame-on-you prizes exist or have existed, among them the Worst Lobby Award, the Angry Mermaid Award, the Tuvalu Prize for Climate Change, and the Climate Greenwash Award. As for other NGOs, the use of this tactic is part of a broader repertoire of collective action. AT also uses shareholder activism, an advocacy strategy in partnership with other NGOs, and lobbying. In particular, AT has been involved since 2004 in an organization called Forum Citoyen pour la RSE (Citizen Forum for Corporate Social Responsibility), which organizes public debates on corporate social responsibility (CSR) and advocates for more regulation on this issue. The Prix Pinocchio are strongly connected to other actions that AT has developed to lobby representatives. In particular, it advocated for a 'duty of vigilance' law, which would compel multinational companies to be accountable for their suppliers' activities abroad in terms of social justice, human rights, and environmental damage. This law was passed in 2017.

Analysing this tactic allows us to see several aspects of what is at stake in the contentious interactions between SMOs and companies. The content of the accusations published by the NGO reveals how companies' misbehaviours are categorized, qualified, and valuated. Likewise, the categories and valuations used by companies may be assessed too, since they have gradually developed response strategies, mainly through press releases or emails that they send in response to the NGO's accusations. Most of this debate is public and both sides address the audiences that they intend to convince about the validity of their arguments. 
For this reason, most of the data I used are purposely from public sources and press releases ${ }^{2}$. I gathered all the various documents about the Prix Pinocchio published by AT between 2008 and 2015, accessible through its website or, with the organization's help, from its archives (press releases on the presentation of the prize, reports on activities, communication documents, and so on). This material represents about 150 pages. I conducted a media analysis of articles published on the awards in national and local newspapers (114 articles), identified TV or online programmes that mentioned the prize, and traced various websites that spread information about the prize. I also did some research on the companies nominated, to identify their activities and their different public communication strategies and topics. I also gathered their responses to AT, through press releases or mail. When companies have written directly to AT, these letters have been published on the NGO's website and are considered as public communication. AT may have answered these letters, and in this case this letter is published too. Around twelve letters have been collected, as well as twenty press releases. To obtain information about the link between the Prix Pinocchio and the organization's repertoire of collective action, two interviews were conducted with the person who was in charge of the Prix Pinocchio at AT. Finally, I collected the parliamentary debates on the above-mentioned bill to identify how the valuations of business activities used by representatives refer to the categories proposed by companies or activists. All documents, letters, press releases, and parliamentary debates were read in full, as a sampling strategy would not have been relevant considering the small size of the material collected. The data have been qualitatively analysed following three objectives: to trace the exchanges between companies and the NGO and to identify their audiences; to identify, collect, and compare the categories of valuations used either by the NGO, companies, journalists, or members of parliament; and to identify the connections between the prize tactic and the bill.

\section{The shame-on-you prize tactic: Building and legitimizing alternative valuations of business activities}

Below, I present the different results of my analysis by answering four relevant questions: Why use a shame-on-you prize tactic? Which companies are targeted and why? Why engage in

\footnotetext{
${ }^{2}$ I thank Leopold Jacqueline for his valuable help in collecting the empirical material.
} 
discussions with targeted companies? What is at stake in producing and circulating alternative valuations of business activities?

First, I demonstrate that AT used the shame-on-you prize tactic to receive wide audience attention and that it claimed that it was the expression of the expectations of civil society regarding business activities. Second, I show that AT targeted companies that use ethical arguments in their communication in order to contest the way in which companies promote and valuate their activities as ethical and to challenge these valuations by using other criteria (social justice, human rights, environmental damage). Third, this contention about valuations opened up opportunities for dialogue between the SMO and the targeted companies, in which some companies could co-opt some of the valuation criteria used by AT. Finally, I show that these alternative valuations may have provided normative resources for the adoption of legislation on business activities.

\subsection{Why adopt a shame-on-you prize tactic? Gaining wide audience attention}

Why give companies awards? What is the value added of such a tactic? Essentially, the tactic allows the NGO to capture the attention of different audiences: the companies themselves, activists supporting the cause, a wider public audience, and the media.

First, using shame-on-you prizes offers the advantage of attracting the attention of the economic world, by mimicking and satirizing one of the central functions of markets: competition. Markets are about relative positions (White 2002) and status hierarchies (Podolny 1993). The business world produces and uses many instruments for rating and ranking companies, one of the most famous being the Fortune 500 ranking. These rankings are considered as an instrument for both disclosing and enhancing competition. This idea of commensurability has been studied extensively in the sociological literature as a way of organizing social worlds (Espeland and Stevens 1998; 2007). Sharkey and Bromley (2015) have identified three effects of rating or ranking organizations. First, it formalizes and publicizes each company's position relative to its peers, increasing competition between them. Secondly, it fosters inter-organizational learning by allowing companies to identify high-performing practices and adopt them. Finally, it helps to identify shared norms in a field. The Prix Pinocchio utilized all of these aspects, as they rewarded the worst practices and ranked companies but according to their own criteria, with the intention of spreading their normative vision. Through this tactic, the SMO sought to pinpoint the relevant and legitimate criteria that could set the standards for suitable business 
behaviour. The Prix Pinocchio aimed to redefine what should count in evaluating high-standard economic activity: not only profit and economic development, but also alternative categories related to the common good, such as human rights, transparency, or environmental protection. There are many examples of the attention given to the Prix Pinocchio by companies or the business world more broadly: primarily through published responses, as well as the relay of information by business-oriented programmes or publications, and a few business associations even mentioned them on their websites.

Secondly, AT sought to attract the largest audience possible, as getting the attention of the targeted company was not its only objective. It used its large activist network to circulate the list of nominated companies and to call for votes. We identified 118 websites that mentioned the list of nominated companies and award-winners at least once between 2008 and 2015: most of them are environmental or social justice organizations. AT also used social media to call for votes or to announce the result of voting in order to increase publicity for its actions and to receive support from a wide audience. Indeed, the organization claimed that the number of votes increased each year: from 4,193 votes in 2008, to 13,017 in 2013, and 61,043 in 2014. The last and final year saw a decrease in the number of people voting $(42,952)$. The organization attributes this decline to the context of the Paris Climate Change Conference (COP21), which attracted most of the attention on environmental issues, and to a decrease in the effectiveness of the action ${ }^{3}$. The voting process was of great importance for AT, as it demonstrated public awareness of the issues raised and the expectations that this audience expressed towards business behaviours. From the point of view of the organization, it increased the legitimacy of its actions and its claims, and it made the NGO a representative of citizens' opinion on CSR issues. The organization of the awards ceremony was another way of drawing the attention of a wider audience: the event was organized in a very humorous tone, in the form of a theatre play that was filmed and posted on the internet. As suggested by Jasper and Poulsen (2015), using humour is a way of recruiting 'strangers' for collective action, i.e., people who do not already support the cause. However, only a few people attended the ceremony and the videos posted did not get more than a few hundred views.

The third and final objective was to get widespread media attention. The SMO informed journalists before the press release, hoping that they would relay the information or contact the

\footnotetext{
${ }^{3}$ After 2015, AT decided to stop the Prix Pinocchio. Initially, the organization just wanted to take some time and make some adjustments, but in the end it decided to not continue its action. One of the reasons is that AT considered that the expected legislation was well on the way to being adopted.
} 
nominated or award-winning companies to make them respond to the accusations. Indeed, the Prix Pinocchio received increasing media attention over the years. In their early years, only two articles were published in the press about the Prix Pinocchio. Since 2010, about thirty articles were published each year, in major national newspapers or press magazines (Le Monde, Libération, L'Express), in local newspapers (Le Parisien, La Voix du Nord, Midi Libre), and web media (Rue89). Several major TV programmes (Capital, Journal de France 2), online news sources (Actu.orange, ecoplus TV), and video blogs mentioned the awards. The newspapers usually adopted a mocking tone towards the award-winning companies, showing a great deal of sympathy to the cause and denouncing companies as cheaters, liars, or having bad practices. One of the main successes of AT's action in terms of gaining media attention was in 2010 when, as part of her TV show, a famous journalist conducted an investigation into a bank that won the Pinocchio greenwashing award the previous year. The programme, which has a large audience, probably contributed to spreading the recognition of the awards beyond solely activists. This media attention may have resulted from the way in which AT chose which companies to target.

\subsection{Which companies to target? Taking advantage of companies' use of ethical arguments in their communication}

Several scholars have demonstrated that activists strategically and methodically choose which companies to target. Firms that are at the vanguard of innovation and occupy elite positions in their field, that are the leaders of an industry, that spend large amounts of money on advertising, or that have high reputation rankings might be targeted more often than other companies (Bartley and Child 2014; King 2008). Size, status, and reputation, which are usually considered to be strategic assets in the economic world, become points of vulnerability in contentious interactions with social movement organizations, because SMOs can benefit from their visibility to achieve publicity for their own actions. Unsurprisingly, AT used a similar strategy. Among the ninety-six companies nominated between 2008 and 2015 for the Prix Pinocchio, most were leaders of their industries at the international or national level (such as Total, Vinci, Groupe Bolloré, BNP Paribas, Crédit Agricole, or EDF, to name a few). This is especially true for the fifteen that were nominated more than once (from two to six times for the most frequently nominated company), or for the twenty-four that received an award. As a result, some companies received multiple awards during the period; one received three awards (Areva) and three received two awards (EDF, Bolloré, Eramet). 
However, firms were not targeted solely because of their status. AT had a specific procedure for the selection of nominated companies. It organized consultations within its network of partner organizations to select companies that had already been identified or targeted for their misbehaviour regarding social justice or environmental damage. The nomination of a company had to be based on local investigations by activist organizations. Indeed, half of the twenty-four award-winners had already been targeted by a press release published by AT, usually in response to an announcement made by the company. Therefore, the shame-on-you prize tactic acted as a continuation of previous naming-and-shaming actions by AT or its partners, in order to take advantage of the contentious dialogue that had already begun. Overall, the company that was nominated the most times (six times) is also the one most frequently targeted by press releases (nineteen times) by other partner SMOs for its greenwashing communication.

Consequently, whereas the literature considers that contentious interactions start with activist campaigns, here activists consider the starting point to be a company's misleading communication and its fallacious publicity of ethical activities, such as a press release about a new activity, the publication of a CRS report, or a new advertisement. Therefore, from the SMO's point of view, the company is the offender, as it offended the legitimate sense of ethics that the NGO wants to claim. The Prix Pinocchio were intended to hold firms accountable to the ethical discourses that they themselves profess and to challenge the company's valuation of what is ethical by contrasting it with evidence about unethical practices: it is a conflict of valuation.

The NGO's press releases contested what companies promoted as environmental or social justice benefits by re-qualifying these activities as human rights violations, environmental damage, or greenwashing practices. They may level three types of accusations. The first concerns greenwashing practices, where companies abusively use eco-friendly arguments in their communication. For example, the use by Areva (awarded in 2008) of the slogan 'Our energies have a future, a future without any $\mathrm{CO}_{2}$ ' was considered to be greenwashing, since the company operates in the nuclear energy industry. Similarly, the fact that Crédit Agricole (awarded in 2010) claimed to provide 'green banking' was contested by AT, which highlighted in its press release the bank's funding of a coal power plant in South Africa. A second category of accusation is related to local impacts on the environment or workers' rights. Auchan was given the 2013 award for refusing to compensate the victims of the Rana Plaza disaster, the collapse of a factory in Bangladesh that killed 1,100 workers that year. Shell received an award in 2014 for its shale gas extraction projects, accused of financial opacity and environmental 
risks. The third category concerns the externalities of economic activities on local populations. Veolia, a utilities company, was given an award in 2013 following accusations of privatizing water in India, which resulted in increased prices and conflicts with local populations.

In their press releases, activists denounce the categories of valuation used by companies, such as 'ambitious project', 'ethical objectives', and 'greening', as hypocritical and false. They mention 'a gap between public discourse and reality' and suggest alternative valuations for the same activities based on their own criteria, such as social justice, workers' rights, respect for local populations, and environmental preservation. Their action is less about undermining reputations than about contesting the criteria used by companies to promote and value their activities.

\subsection{Why engage in discussion with companies? Contesting the relevant criteria for valuating economic activities and encouraging companies to adopt them}

Being very active in attracting the attention of a wide audience gave AT the opportunity to publicly challenge companies' valuations and communications. But the organization also worked on engaging its targeted companies in dialogue. For this purpose, the final results and the names of the awarded companies were not released as a surprise. Companies were informed that they would be nominated and had the opportunity to respond before the publication of the press release. In this way, activists avoided being sued for libel. More importantly, it was a way to open a discussion with the companies, to force them into dialogue. But why enter such contentious interactions with companies if the NGO knows that companies may cheat and lie? I suggest that these interactions are about negotiating and publicly challenging the categories of valuation in the economy.

AT presented the results of the awards using the classical vocabulary of contention: companies were accused of 'monopolization of water or land resources', 'undemocratic processes of negotiation with the local population', 'environmental damage', 'severe pollution', 'violation of food sovereignty', 'conflicts of interest', 'bribery', or 'opacity'. This vocabulary intended to establish categories for valuating companies' practices and images, by incorporating the costs of these practices on the environment, the local population, or social justice. These qualifications did not only concern firms' practices but also those of their suppliers and subcontractors. Firms' valuations were challenged by the SMO's discourse, which included different types of criteria and all supply chain activities. 
Although many companies remained silent during the first few years of existence of the Prix Pinocchio, most of them gradually began to react by publishing press releases or by sending letters to the activist organization. Most of the companies' reactions used one of the two following lines of argumentation. The first was to reject the activists' accusation by disqualifying it as 'a value judgement', 'illegitimate', or an 'unfounded accusation'. This is clearly an attempt to refute the ONG's competency or legitimacy to valuate business activities. The second line of argumentation, which gradually became more common in companies' responses, was to describe the actions that had already been taken by the company regarding the issues raised by the shame-on-you award. This discourse does not represent a concession to the ONG's claims. Rather, companies engaged in an argumentation to convince AT, as well as a broader audience, of the accuracy and legitimacy of their valuations. What is interesting is that in some of their letters companies use AT's categories and criteria to valuate economic activities such as social benefits or the accountability of their suppliers' practices. For example, after being accused of child labour in its suppliers' factories in 2014, Samsung responded to AT by stating 'we deeply care about the health and safety of all our employees and employees at our suppliers'. The firm mentions various ways of monitoring its suppliers and the measures taken to improve the verification of the age of employees. It states that it 'believes it is our responsibility to hold ourselves and our suppliers to the highest standards of labor practices' and that it has developed a child labour prohibition policy in China that should "pave the way for other companies'. The letter also mentions the accuracy of 'world-class working conditions' and 'international labour standards' in monitoring its suppliers. Another company mentions in its letter that it has 'the objective of providing wider social and economic benefits to the population', and that it will 'promote the development and empowerment of the people'. Gradually, more companies re-evaluated their own activities through the categories suggested by activists, finding it legitimate to endorse some social missions or to be accountable for the activities of their suppliers or funding recipients.

The foot-in-the-door tactic allowed AT to go further and press its claims in its reactions to companies' responses.

We published their responses, which gave us the opportunity to answer and then argue more and show their lies.

(Interview with the person who was in charge of the Prix Pinocchio, 12 July 2017) 
The letters are signed by the president of AT and not by the person who was in charge of the Prix Pinocchio. They insistently acknowledge that the companies implicitly accept the criteria suggested by activists to define ethical business activities. For example, the president of AT underlines in his letter that 'Crédit Agricole recognizes that it has responsibility beyond the funding of projects', which let him push forward his arguments. As the bank's letter presents the company's green policy, which excludes from its funding activities any energy company with more than 20 per cent of its production based on coal, AT's letter refuses to recognize this policy as environmentally responsible, arguing that all coal-related activities should be abandoned. The same method of disqualifying companies' valuations is used by AT to respond to the letter from EDF (a major energy company), which highlighted its decrease in greenhouse gas emissions:

Your argument does not outweigh the real increase in your $\mathrm{CO}_{2}$ emissions. Indeed, you explain that emissions in tonnes of $\mathrm{CO}_{2}$ per kilowatt-hour of production decreased between 2006 and 2013. This does not change anything regarding the data available in your 2013 activity report: your total emissions in 2013 reached 80.6 million tonnes, whereas they were 79.8 million tonnes in 2012.

(Letter from the president of AT to EDF, 16 October 2014)

The argument in AT's letter demonstrates to the company that a strategy of producing more electricity in a less polluting way cannot be considered eco-friendly; the only legitimate policy according to activists would be to reduce energy production and to favour renewable energies. Re-valuation can apply to environmental policies as well as human rights policies. In 2014, Total was nominated for the Prix Pinocchio because of its practices concerning gas flaring. It was accused of having expropriated local populations without democratic consultation. In its response, the company argued that it had received an authorization for gas flaring and that the local population had been consulted through their representatives, an assembly of the people. In its answer, the president of AT again produced an alternative valuation of the company's behaviour. He cited the international law on gas flaring, contrasting what the company presented as an authorized local practice with the provisions of international regulations. He also denied that the local population was consulted, pointing to a conflict of interest since several members of the assembly worked for the company. 
In a few cases, some companies went even further in their responses, acknowledging the accusations and mentioning their desire to engage in co-operation with civil society in order to design appropriate policies on financial disclosure or environmental protection.

\begin{tabular}{|c|c|c|c|}
\hline \multicolumn{2}{|c|}{ Category of valuation } & Companies & Activists \\
\hline \multirow[b]{3}{*}{ Ethics } & Valuation & Ethical & Unethical \\
\hline & Claim & $\begin{array}{l}\text { Implementing } \\
\text { international } \\
\text { labour standards }\end{array}$ & $\begin{array}{l}\text { Child labour in } \\
\text { the company's } \\
\text { suppliers' } \\
\text { factories }\end{array}$ \\
\hline & Criteria & $\begin{array}{l}\text { Complying with } \\
\text { the regulation, } \\
\text { implementing } \\
\text { best-in-class } \\
\text { standards }\end{array}$ & $\begin{array}{l}\text { Being } \\
\text { accountable for } \\
\text { one's } \\
\text { subcontractors' } \\
\text { activities }\end{array}$ \\
\hline \multirow{3}{*}{ Climate change } & Valuation & Sustainable & Unsustainable \\
\hline & Claim & $\begin{array}{l}\text { Decrease in the } \\
\text { rate of GHG } \\
\text { emissions per } \\
\text { unit of } \\
\text { electricity } \\
\text { produced }\end{array}$ & $\begin{array}{l}\text { Increase in the } \\
\text { total amount of } \\
\text { GHG emissions } \\
\text { produced }\end{array}$ \\
\hline & Criteria & $\begin{array}{l}\text { Improve the } \\
\text { GHG emission } \\
\text { efficiency of } \\
\text { energy } \\
\text { production }\end{array}$ & $\begin{array}{l}\text { Decrease in total } \\
\text { GHG emissions }\end{array}$ \\
\hline
\end{tabular}

Table 1: Examples of disputes on the valuation criteria between companies and activists 
In these contentious interactions, activists present alternative valuation criteria to those used by companies in their communications, but they also encourage companies to adopt these criteria.

\subsection{What produces these alternative valuations? Providing normative resources to push forward public regulation}

As mentioned earlier, AT's shame-on-you prize tactic was part of a broader repertoire of collective action, and it was strongly linked to a more classical advocacy action that the organization developed to push forward public regulation of CSR practices and more specifically to make globalized companies accountable for the activities of their suppliers. Since 2004, AT has been part of an activist network named the Citizen Forum for CSR, along with several partners (including Amnesty International, Greenpeace, and WWF). The Citizen Forum has advocated and lobbied for the regulation of the activities of multinational companies, especially regarding the unethical practices of their suppliers. The organization has lobbied representatives, especially following the election of François Hollande's left-wing government in 2012. In 2013, AT and other organizations from the Citizen Forum joined a consultation group, called the CSR Platform, composed of business associations, labour unions, NGOs, and members of public institutions, established by Prime Minister Jean-Marc Ayrault. The group was designed to produce information about social, environmental, and governance issues related to CSR. Two years later, a group of representatives from the Socialist Party and the Ecologist Party introduced a bill to parliament to compel parent companies to have a monitoring plan ('plan de vigilance') for their suppliers, subsidiaries, and subcontractors. This regulation, which translates into French law the United Nations' (UN) general guidelines for vigilance regarding overseas companies' activities, is intended to make multinational companies accountable for the activities of their upstream supply chain in France and abroad, and was called the 'Duty of Vigilance Law'.

For AT, the Prix Pinocchio were clearly a tactic designed to advance its demand for the duty of vigilance law, as stated by the person in charge of the awards:

The Prix Pinocchio were part of our actions and our broader campaigns on the issue of regulating companies, and in particular globalized companies. And finally we got a response to our requests, since, in 2013, a first bill on the duty of vigilance of multinational companies was tabled in the Assembly. 
(Interview with the person who was in charge of the award at AT, 22 May 2017)

A strong connection was built between actions at the parliamentary level and the efforts of activists, including the Prix Pinocchio, as evidenced by parliamentary debates and different press releases. The representatives regularly mentioned that the bill was the result of important consultations with NGOs and civil society actors, insisting that it corresponded to the expectations of a wide range of stakeholders, from citizens to consumers, shareholders, and even some companies themselves. During the debates, the pro-bill representatives recalled that the project received the support of 250 European NGOs and 160,000 citizens. AT staff members, including the person in charge of the Prix Pinocchio, were heard during the discussion of the bill. In 2013, pro-bill representatives also made extensive use of the dramatic case of the Rana Plaza collapse to emphasize the need to force companies to monitor their suppliers, and a year later the Prix Pinocchio gave an award to one of the companies who used a subcontractor at the collapsed factory. Symmetrically, the Prix Pinocchio press releases regularly mentioned the progress of the bill, denouncing the lobbying of the multinational corporations or right-wing representatives who opposed it. The Citizen Forum, as well as AT and its partners, regularly published press releases about the bill.

More symptomatically, an analysis of the parliamentary debates demonstrates how they significantly echo the contentious valuation of business activities that we described above. The debates did not pit representatives supporting civil society valuations against representatives supporting business valuations, but rather representatives considering the two valuations to be incompatible against representatives combining the two valuations. The bill's opponents (especially at the Senate, which was mostly right-wing) highlighted the high risk for French companies of becoming uncompetitive, emphasizing the incompatibly of civil society claims with business interests. Meanwhile, pro-bill representatives stated that 'competitiveness cannot ignore human rights', combining activists' claims (human rights) with the valuation of economic performance. Most of the discourse of supporters of the bill combined conventional and existing economic valuations, such as 'competitiveness', 'reputation building', 'brand protection', and 'meeting consumers' expectations' with categories such as environmental protection, human rights, or workers' rights, while opponents claimed that these valuations were contradictory. Pro-bill representatives recalled that several companies supported the bill, as expressed in this quote from a left-wing senator, combining business performance objectives 
(reputation, competitiveness, market share) and social objectives (vigilance, human rights, sustainability):

These companies consider that competitiveness cannot ignore respect for human rights. These groups have another reason to hope for the adoption of the bill: the importance they give to customers! They want to enhance their reputation and protect their brand by becoming vigilant and sustaining good practices. They want to be more competitive by being more virtuous than their competitors, and by not relocating, conducting social or environmental dumping, or disrespecting human rights.

(Senate, session of 18 November 2015, intervention of a left-wing pro-bill representative)

Another pro-bill representative stated 'This regulation is of great interest to large companies, because reputation is a commercial asset of great value', connecting business interests with regulatory interests. When the finance minister defended the bill at the National Assembly, he claimed that the regulation 'is about helping [companies] to be responsible and preventing, not punishing. It is about regulating in order to give shareholders and consumers more confidence in our companies', emphasizing that it was in the companies' interest.

The law was finally adopted in April 2017. Its first article sets the obligation for large companies to implement a vigilance plan to identify and prevent risks of violations of human rights and freedoms, environmental damage, or physical injuries resulting from their own activities, those of the companies they control, or those of subsidiaries over which they exert influence. Activist groups have acknowledged the law to be a major advancement, even though most of them regret that the law only covers large companies (of more than 10,000 employees) and that the burden of proof still falls on the victims' shoulders.

My point is not that the Prix Pinocchio had a direct effect on the passing of the bill. I am not defending a causal perspective, but rather claiming the mediated effects of anti-corporate disruptive actions. Following Young and Schwartz (2014), I consider that targeting companies may have some effects on public decisions.

I suggest that social movement organizations work on producing and circulating alternative categories and criteria of valuations of economic activities in order to change the normative references used in the economic world. They make them legitimate by arguing that they express 
the will and expectations of civil society. And they make them acceptable to economic actors by persuading companies to adopt them through tactics aimed at opening up a dialogue, encouraging companies and other actors to see activists' claims as compatible with business interests. These changes in the normative references may in turn influence public policy, as public decision-makers will consider that such a regulation is expected by civil society and that companies are already prepared for it. If anti-corporate activism has any outcomes in terms of market changes, these are undoubtedly indirect. Among the different mediation effects, I suggest taking into consideration the circulation of alternative normative valuations of business activities in different social spaces, such as the media, the business world, public opinion, and public policy.

\section{Conclusion}

In the conclusion of this paper, I discuss its two main contributions. The first is related to the puzzling question of how to assess the outcomes of social movements (Gamson 1990; Giugni 1998). In the context of the development of anti-corporate movements, some studies have focused on causal mechanisms, isolating the contribution of specific tactics, such as namingand-shaming campaigns or corporate boycotts, on certain economic values, such as stock prices or reputation rankings (Bartley 2007; King and Soule 2007). These approaches artificially isolate one tactic, even though most activist organizations use a wide repertoire of tactics and strategies and may have many different targets. More recently, the literature has highlighted the role of environmental factors and mediated mechanisms in assessing social movement outcomes (Amenta 2006; King 2008). The outcomes might then be considered more accurately as impacts, consequences, or influences, as suggested by Amenta and Polletta, who refer to 'cultural changes that are attributable to movements' (Amenta and Polletta 2019). These cultural changes include a wide range of aspects, such as creating political identities, categories, ideas, or lifestyles that circulate in the public space through the media but also in different institutions, including economic institutions. Drawing on this case of anti-corporate activism, I suggest that social movement organizations are influential through the normative values that they legitimize and circulate in the social space. In their effort to change markets and the economy, activists create political categories, such as the ethical consumer or the citizenconsumer (Dubuisson-Quellier 2013a), to whom they attribute specific expectations regarding suitable, ethical, accountable, and legitimate economic activities. They engage in contentious 
interactions with companies that gradually make some of them adopt their valuation criteria. These cultural and normative changes may in return foster market regulation (Dixon et al. 2016), as public decision-makers find support for it both in public opinion and the business world. Consequently, anti-corporate activism should mainly be considered as another way for social movements to target political institutions and achieve social change.

The second contribution of this paper is in the field of economic sociology. Debates about the dialectic between stability and change in markets have been lively in this field of research. Scholars have acknowledged the stability of the economic order, in terms of the rules and power relations that exist within a market (Beckert 2009; 2010; White 2002), but they have also considered the possibility of change. Fligstein and McAdam (2012) provided a theoretical framework that considers the role of disruptive events in changing markets. Conflicts created by the challenging of the dominant position of certain economic actors produce disruptive events that can lead to changes in the market order. But, in their opinion, social movement interventions are exogenous, considered as external shocks. I suggest another perspective, following Zelizer's seminal work on how social values shape economic values and vice versa (Zelizer 1979). First, social movements are one of the major drivers of market change, as they constantly, in a more or less contentious manner, provide the business world with normative concerns that challenge existing rules and practices. Secondly, social movements do not act outside of markets but through the numerous interactions they have with economic actors, from contention to collaboration, as well as competition. Thirdly, change in markets occurs from the cultural and normative resources that social movements produce both for new business practices and for changes in regulation.

This work is supported by a public grant overseen by the French National Research Agency (ANR) as part of the "Investissements d'Avenir" programme LIEPP (reference: ANR-11LABX0091, ANR-11-IDEX-0005-02). 


\section{Reference list}

Amenta, E. (2006). When Movements Matter: The Townsend Plan and the Rise of Social Security. Princeton: Princeton University Press.

Amenta, E., \& Polletta, F. (2019). The Cultural Impacts of Social Movements, Annual Review of Sociology, 45, 279-99.

Balsiger, P. (2016). Moral Struggles in Markets: The Fight against Battery Cages and the Rise of Cage-Free Eggs in Switzerland. European Journal of Sociology, 57 (3), 419-50.

Balsiger, P. (2018). Explaining Dynamic Strategies for Defending Company Legitimacy: The Changing Outcomes of Anti-Sweatshop Campaigns in France and Switzerland. Business and Society, 57 (4), 676-705.

Baron, D. (2016). Self-Regulation and the Market for Activism. Journal of Economics and Management Strategy, 25 (3), 584-607.

Bartley, T. (2007). Institutional Emergence in an Era of Globalization: The Rise of Transnational Private Regulation of Labor and Environmental Condition. American Journal of Sociology, 113 (2), 297-351.

Bartley, T., \& Child, C. (2014). Shaming the Corporation: The Social Production of Targets and the Anti-Sweatshop Movement. American Sociological Review, 79 (4), 653-79.

Beckert, J. (2009). The Social Order of Markets. Theory and Society, 38 (3), 245-69.

Beckert, J. (2010). How Do Fields Change? The Interrelations of Institutions, Networks, and Cognition in the Dynamics of Markets. Organization Studies, 31 (5), 605-27

Beckert, J., \& Aspers, P. (2010). The Worth of Goods: Valuation and Pricing in the Economy. Oxford: Oxford University Press.

Berthoin Antal, A., Hutter, M., \& Stark, D. (eds.) (2015). Moments of Valuation: Exploring Sites of Dissonance. Oxford: Oxford University Press.

Den Hond, F., \& de Bakker, F. G. A. (2007). Ideologically Motivated Activism. How Activist Groups Influence Corporate Social Change Activities. Academy of Management Review, $32(3), 901-24$.

Dewey, J. (1939). Theory of Valuation. In International Encyclopedia of Unified Science 2 (4): $1-67$.

Dixon, M., Martin, A. W., \& Nau, M. (2016). Social Protest and Corporate Change: Brand Visibility, Third-Party Influence, and the Responsiveness of Corporations to Activist Campaigns. Mobilization, 21 (1), 65-82. 
Dubuisson-Quellier, S. (2013a). From Qualities to Value: Demand Shaping and Market Control in Mass Consumption Markets. In J. Beckert \& C. Musselin (eds.), Constructing Quality: The Classification of Goods in Markets (pp. 247-67). Oxford: Oxford University Press. Dubuisson-Quellier, S. (2013b). A Market Mediation Strategy: How Social Movements Seek to Change Firms' Practices by Promoting New Principles of Product Valuation. Organization Studies, 34 (5-6), 683-703.

Dubuisson-Quellier, S. (2013c). Ethical Consumption. Halifax, Canada: Fernwood Publishing. Espeland, W., \& Stevens, M. (1998). Commensuration as a Social Process. Annual Review of Sociology, 24, 313-43.

Espeland, W., \& Stevens, M. (2007). Ranking and Reactivity: How Public Measures Recreate Social Worlds. American Journal of Sociology, 113 (1), 1-40.

Fligstein, N., \& McAdam, D. (2012). A Theory of Fields. New York: Oxford University Press. Fourcade, M. (2011). Cents and Sensibility: Economic Valuation and the Nature of 'Nature'. American Journal of Sociology, 116 (6), 1721-77.

Gamson, W. (1990). The Strategy of Social Protest. Belmont, CA: Wadsworth Publishing Company.

Giugni, M. (1998). Was it Worth the Effort? The Outcomes and Consequences of Social Movements. Annual Review of Sociology, 24, 371-93.

Glickman, L. (2009). Buying Power. A History of Consumer Activism in America. Chicago: University of Chicago Press.

Jackson, G., \& Brammer, S. (2014). Introducing Grey Areas: The Unexpectedly Weak Link between Corporate Irresponsibility and Reputation. Socio-Economic Review, 12, 154-66. Jasper, J., \& Poulsen, J. (1995). Recruiting Strangers and Friends: Moral Shocks and Social Networks in Animal Rights and Anti-Nuclear Protests. Social Problems, 42 (4), 493-512.

Karpik, L. (2010). Valuing the Unique: The Economics of Singularities. Princeton: Princeton University Press.

King, B. (2008). A Political Mediation Model of Corporate Response to Social Movement Activism. Administrative Science Quarterly, 53 (3), 395-421.

King, B. (2011). The Tactical Disruptiveness of Social Movements: Sources of Market and Mediated Disruption in Corporate Boycotts. Social Problems, 58 (4), 491-517.

King, B. (2014). Reputational Dynamics of Private Regulation. Socio-Economic Review, 12, 200-6. 
King, B., \& Soule, S. (2007). Social Movements as Extra-Institutional Entrepreneurs: The Effect of Protests on Stock Price Returns. Administrative Science Quarterly, 52 (3), $413-$ 442 .

King, B., \& Pearce, N. (2010). The Contentiousness of Markets: Politics, Social Movements, and Institutional Change in Markets. Annual Review of Sociology, 36, 249-67.

Kjellberg, H., \& Mallard, A. (2013). Valuation Studies? Our Collective Two Cents. Valuation Studies 1 (1): 11-30.

Locke, R. (2013). The Promise and Limits of Private Power: Promoting Labor Standards in a Global Economy. New York: Cambridge University Press.

McDonnell, M., \& King, B. (2013). Keeping up Appearances: Reputational Threat and Impression Management after Social Movement Boycotts. Administrative Science Quarterly, 58 (3), 387-419.

McDonnell, M., King, B., \& Soule, S. (2015). A Dynamic Process Model of Private Politics: Activist Targeting and Corporate Receptivity to Social Change. American Sociological Review, 80 (3), 654-678.

Podolny, J. (1993). A Status-Based Model Market Competition. American Journal of Sociology, 98 (4), 829-72.

Radin, M. (1996). Contested Commodities. Cambridge, MA: Harvard University Press.

Raeburn, N. (2004). Changing Corporate America from Inside Out. Lesbian and Gay Workplace Rights. Minneapolis: University of Minnesota Press.

Sharkey, A., \& Bromley, P. (2015). Can Ratings Have Indirect Effects? Evidence from the Organizational Response to Peers' Environmental Ratings. American Sociological Review, 80 (1), 63-91.

Soule, S. (2009). Contention and Corporate Social Responsibility. New York: Cambridge University Press.

Stark, D. (2009). The Sense of Dissonance. Accounts of Worth in Economic Life. Princeton: Princeton University Press.

Trentmann, F. (2001). Bread, Milk and Democracy: Consumption and Citizenship in Twentieth-Century Britain. Oxford: Berg Publishers.

White, H. C. (2002). Markets from Networks: Socioeconomic Models of Production. Princeton: Princeton University Press. 
Young, K., \& Schwartz, M. (2014). A Neglected Mechanism of Social Movement Political Influence: The Role of Anticorporate and Anti-Institutional Protest in Changing Government Policy. Mobilization, 19 (3), 239-60.

Zelizer, V. (1979). Human Values and the Market: The Case of Life Insurance and Death in $19^{\text {th }}$-Century America. American Journal of Sociology, 84 (3), 591-610. 